\title{
Anfis Based Thrust Estimation of a Small Rotary Wing Drone
}

\author{
Hüseyin Şahin ${ }^{1 *}$, Tuğrul Oktay², Mehmet Konar ${ }^{3}$ \\ ${ }^{1}$ Ankara Yıldırım Beyazıt Üniversitesi, Meslek Yüksekokulu, Uçak Teknolojisi Bölümü, Ankara, Türkiye (ORCID: 0000-0003-0464-2644) \\ ${ }^{2}$ Erciyes Üniversitesi, Havacılık ve Uzay Bilimleri Fakültesi, Uçak Mühendisliği Bölümü, Kayseri, Türkiye (ORCID: 0000-0003-4860-2230) \\ ${ }^{3}$ Erciyes Üniversitesi, Havacılık ve Uzay Bilimleri Fakültesi, Uçak Elektrik Elektronik Bölümü, Kayseri, Türkiye (ORCID: 0000-0002-9317-1196)
}

(İlk Geliş Tarihi 17 Şubat 2020 ve Kabul Tarihi 23 Mart 2020)

(DOI: 10.31590/ejosat.694721)

ATIF/REFERENCE: Şahin, H., Oktay, T., \& Konar, M. (2020). Anfis Based Thrust Estimation of a Small Rotary Wing Drone. Avrupa Bilim ve Teknoloji Dergisi, (18), 738-742.

\begin{abstract}
Unmanned Aerial Vehicles (UAVs) has an increasingly application for military and civilian fields. Currently, UAVs can perform many tasks such as search-rescue, surveillance by safely. UAVs are specifically designed for their using purpose. The designs of UAVs are an important and long process. It is necessary to evaluate many parameters in the thrust system design. Because of thrust system is the most important system of UAVs. Traditional thrust system design is a trial and error method that is costly and ineffective. In this study, we examined that UAVs which use brushless motor in thrust system. The force generated by the thrust system has been estimated by using the Adaptive Neuro-Fuzzy Inference System (ANFIS). In the ANFIS model, the thrust force estimation was made by using propeller and motor information. RCbenchmark 1580 model dynamometer was used to measure the accuracy of the ANFIS estimates. Mean square error (MSE) was used to compare test data and ANFIS model. Low MSE ratio shows that ANFIS model is near to real data.
\end{abstract}

Anahtar Kelimeler: Electric UAVs, Thrust, ANFIS.

\section{Introduction}

In recent years, the aviation industry and the airline transportation sector has developing rapidly. Along with these developments, many scientific studies have been conducted in aviation. Aircrafts, which are being used in both military and civilian sectors, can complete many complex tasks. In order to fly safely and quickly a UAVs, air is moved and the aircraft flies with the help of aerodynamic forces. The most effective solution for moving air is to rotate the propeller [1-3]. Preliminary short results are presented in [4].

The section of the propeller and engine selection are among the most important criteria affecting the aircraft's performance. These criteria affect the thrust system performance. Its performance in the thrust system is also a factor that determines the endurance, range, take-off distance, fuel consumption, maximum speed and payload capacity of UAVs. When using the appropriate thrust system, while the endurance time, range, maximum speed, payload capacity and acceleration increase, the distances required for take-off and landing, fuel consumption must be reduced [5-8].

UAV's are designed specifically for many tasks. More than one thrust system can be designed during the design phase. Experimental testing of a selected thrust system configuration is a long and costly process. Since this experiment takes a long time to be carried out, the design process will also be extended [9-12].

In this study, it is aimed to estimate the propulsion power with the help of ANFIS to facilitate the design of the thrust system. For this purpose, the E-Max GT-2815 brushless motor used in electrically driven UAVs was tested with different propellers. The estimation of the thrust value was made with the help of ANFIS using the data obtained in this test procedure.

\footnotetext{
* Sorumlu Yazar: Ankara Yıldırım Beyazıt Üniversitesi, Meslek Yüksekokulu, Uçak Teknolojisi Bölümü, Ankara, Türkiye, ORCID: 0000-00030464-2644, husahin@ybu.edu.tr
} 


\section{ANFIS (Adaptive Network Based Fuzzy Inference System)}

ANFIS is a kind of fuzzy logic and artificial neural network system. Takagi-Sugeno is an artificial neural network method based on fuzzy inference system. It is used in modeling nonlinear functions and estimating the resulting function of systems containing nonlinear functions [13-15].

ANFIS has the feature of determining the rules used in the problem or making changes on the determined rules. Therefore, ANFIS can be used in many prediction problems. The ANFIS structure consists of 5 sections (layers) (Figure 1) [16]. The operations performed in these sections are completed as follows.

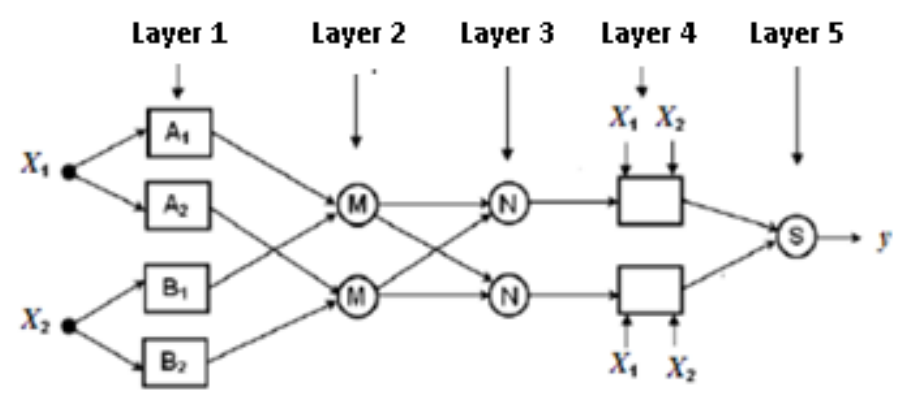

Figure 1. ANFIS structure [16]

In layer 1, blurring is performed. At this stage, ANFIS separates the input values into fuzzy sets. In layer 2, the rule operation is performed. This layer describes the number of fuzzy logic deduction rules in the sugeno type. The operation is performed by multiplying the entries in the first layer. In layer 3, normalization is performed. In this layer, it is the normalization of each node by accepting the input value of all the nodes from each node rule layer. This is done by dividing the output value of the rule operation by all output values. In layer 4, clarification is done. A weighted result value of the rule given in each node is calculated. In layer 5, collection is carried out. Each output value in the clarification layer is summed resulting in the true value of the ANFIS system.

\section{Experimental Study and Simulation}

In the study, using the 1580 model dynamometer produced by RCbenchmark, the thrust force created by different propulsion systems was calculated [12]. Calibrating before using the dynamometer ensures that results are more clearly obtained.

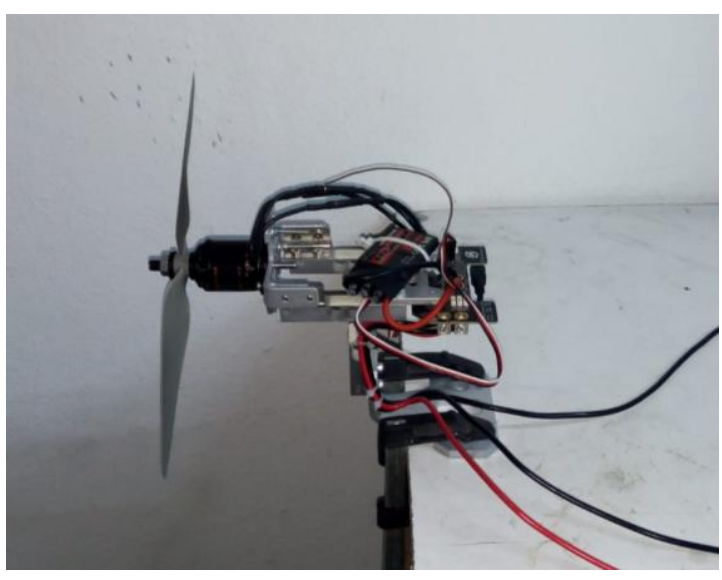

Figure 2. RCBenchmark 1580 model dynamometer

The results of the experimental study carried out with the help of dynamometer were obtained with the help of computer interface. The performance of the thrust system designed for UAVs was examined with this experiment. In the study, the impulse test of the E-Max GT-2815 model brushless DC motor was carried out with 1050, 1145 and 1180 plastic propellers. The electrical power required for the motor to turn during the test was provided with a Electronic Speed Controller (ESC) and a lipo battery which capacity of 11.1 Volts (3 cells, 3S) 1500mAh. 


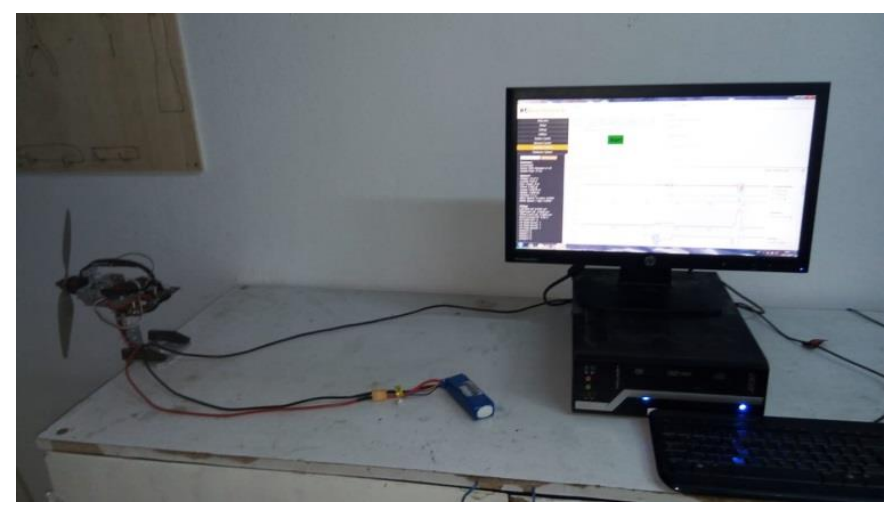

Figure 3. Experimental study.

The signals of the ESC were used given with the help of the computer interface. In order to rotate the engine, 21 different pulsewidth modulation (PWM) signals were sent to the ESC at intervals of $100 \mu$ s between $1000 \mu$ s and $2000 \mu$ s. The engine was recovered by waiting for 2 seconds at each signal. Thus, the first burst current prevents the motor efficiency from decreasing. With these signals, the rotation speed of the engine varied between 0-8600RPM. The same experiment was repeated for all three propellers and 63 different data sets were obtained. The use of three different propellers made of the same materials and with the same methods has allowed an objective comparison of the propeller performances.

The propeller diameter $(\mathrm{d})$, propeller pitch $(\mathrm{p})$, Revolutions Per Minute (RPM) value of the brushless motor and propeller efficiency values were determined as the input parameters for the ANFIS model. The thrust force value is chosen as the output parameter that is to be calculated. The representation of the created model is given in figure 4 .

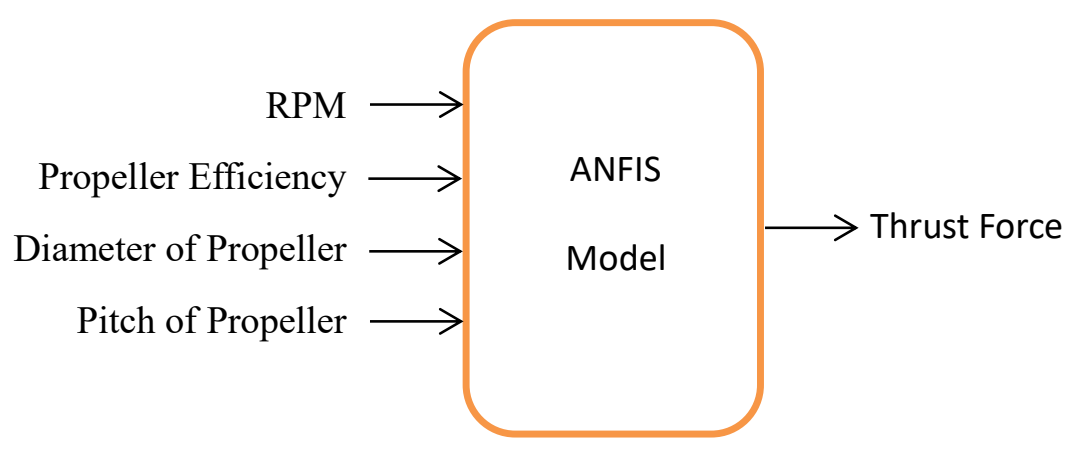

Figure 4. ANFIS model structure

While 52 data sets out of 63 data sets obtained from the experimental results were used as training data of ANFIS models, 9 data sets were used for testing the created models. The data of 3002, 5983 and $8468 \mathrm{rpm}$ values were chosen as test data from the results with 10x50 propeller. The data of 1859, 4429 and $6535 \mathrm{rpm}$ values were chosen as test data from the results with $11 \mathrm{X} 45$ propeller. The data of 2970, 5208 and $6783 \mathrm{rpm}$ values were chosen as test data from the results with $11 \mathrm{X} 80$ propeller. Thus, the selection of test values in different ranges of different propellers enabled the performance of the test operation to be observed in different ranges.

Minimum Square Error (MSE) was used to compare the performance of modeling studies with ANFIS [16]. The results obtained in the training and testing of the simulations of different model are given in Table 1. Looking at the table, it is seen that the best model is in the ANFIS model, which has 4 rules. In the 4-rule model, the comparison of the experimental values with the RPM input and the model values is given in figure 5. The comparison of the experimental test values and the model values against the RPM input in the test operation is given in figure 6. Percentage error values in the test operation are given in figure 7.

Table 1. Comparison the performance of different ANFIS models

\begin{tabular}{|c|c|c|}
\hline \multirow{2}{*}{$\begin{array}{c}\text { Rules } \\
\text { Number }\end{array}$} & \multicolumn{2}{|c|}{ MSE } \\
\cline { 2 - 3 } & Training & Test \\
\hline 2 & $2,27 \mathrm{E}-02$ & $1,65 \mathrm{E}-02$ \\
\hline 3 & $1,19 \mathrm{E}-02$ & $7,82 \mathrm{E}-03$ \\
\hline 4 & $1,41 \mathrm{E}-03$ & $2,02 \mathrm{E}-04$ \\
\hline
\end{tabular}




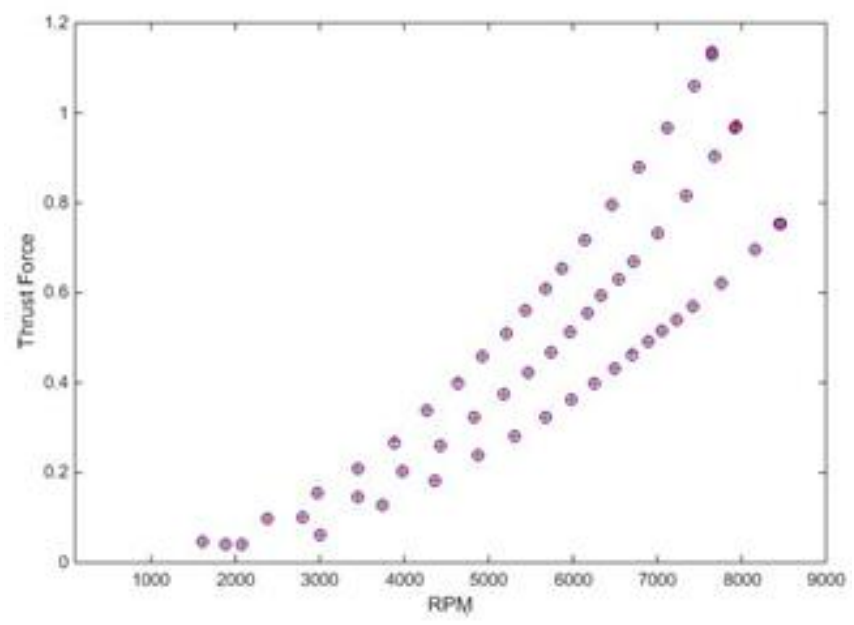

Figure 5. Comparison of experimental values with RPM input value in the training operation.

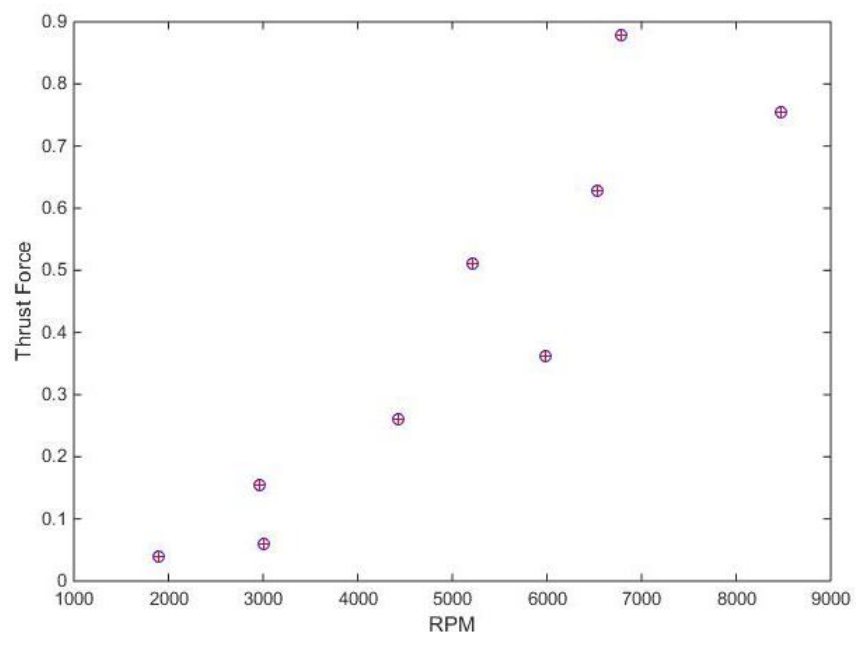

Figure 6. Comparison of experimental values with RPM input value in the test operation.

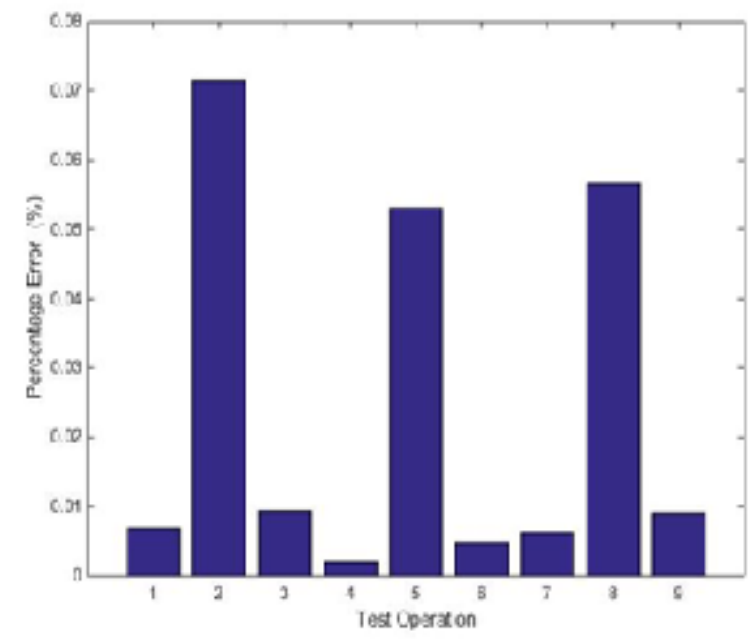

Figure 7. Percentage error values in the test operation

When the figures 5 and 6 are analyzed, the values marked "o" are the actual values obtained experimentally, while the values marked "+" are the results of the ANFIS model with 4 rules. From the figures, it can be said that the real experimental values and the 4-rule ANFIS values are in harmony. Low MSE value indicates that model is successful. In addition, another effect of model success is the low percentage error in the testing process. 


\section{Result}

One of the most important issues to be considered in the UAVs design is the design of the propulsion system. Many parameters must be evaluated in the propulsion system design. Using heuristic algorithm methods in this study makes an important contribution to the design stage. In this study, with the help of ANFIS model, the estimation of the thrust force was made by using the diameter, pitch, RPM and efficiency of propeller values. As a result, the low MSE values obtained in the study show that the real values match the model results. The low percentage error values obtained in the test process show that the modeling is successful.

\section{References}

1. Barton, J. D. (2012). Fundamentals of Small Unmanned Aircraft Flight. Johns Hopkins APL Technical Digest (Applied Physics Laboratory), 31(2), 132-149.

2. Hobbs, A. (2010). Unmanned Aircraft Systems. In Human Factors in Aviation (pp. 505-531). Elsevier Inc. https://doi.org/10.1016/B978-0-12-374518-7.00016-X

3. Nonami K., Kendoul F., Suzuki S., Wang W., N. D. (2010). Fundamental Modeling and Control of Small and Miniature Unmanned Helicopters. In: Autonomous Flying Robots. In Autonomous Flying Robots: Unmanned Aerial Vehicles and Micro\nAerial Vehicles. https://doi.org/10.1007/978-4-431-53856-1

4. Sahin, H., \& Oktay, T., \& Konar, M., (2020). İnsansız Hava Aracı İtki Gücünün Tahmini. Uluslararası 5 Ocak Uygulamalı Bilimler Kongresi, Adana, Türkiye, 3 - 05 January 2020

5. McDonald, R. A. (2014). Electric Propulsion Modeling for Conceptual Aircraft Design. 52nd Aerospace Sciences Meeting. https://doi.org/10.2514/6.2014-0536

6. Gohardani, A. S., Doulgeris, G., \& Singh, R. (2011, July). Challenges of Future Aircraft Propulsion: A Review of Distributed Propulsion Technology and Its Potential Application for the All Electric Commercial Aircraft. Progress in Aerospace Sciences.

7. Sahin, H., \& Oktay, T. (2017). Powerplant System Design for Unmanned Tricopter. The Eurasia Proceedings of Science, Technology, Engineering \& Mathematics, 1, 9-21.

8. Avanzini, G., de Angelis, E. L., \& Giulietti, F. (2016). Optimal Performance and Sizing of a Battery-powered Aircraft. Aerospace Science and Technology. https://doi.org/10.1016/j.ast.2016.10.015

9. Austin, R. (2010). Unmanned Aircraft Systems: UAVS Design, Development and Deployment. In Unmanned Aircraft Systems: UAVS Design, Development and Deployment. https://doi.org/10.1002/9780470664797

10. Chang, T., \& Yu, H. (2015). Improving Electric Powered UAVs' Endurance by Incorporating Battery Dumping Concept. Procedia Engineering. https://doi.org/10.1016/j.proeng.2014.12.522

11. Valavanis, K. P., \& Vachtsevanos, G. J. (2015). Handbook of Unmanned Aerial Vehicles (pp. 1-3022). Springer Netherlands. https://doi.org/10.1007/978-90-481-9707-1

12. Konar, M. (2019). GAO Algoritma Tabanlı YSA Modeliyle İHA Motorunun Performansının ve Uçuş Süresinin Maksimizasyonu. European Journal of Science and Technology, 15, 360-367. https://doi.org/10.31590/ejosat.529093

13. Güler, I., \& Übeyli, E. D. (2005). Adaptive Neuro-Fuzzy Inference System for Classification of EEG Signals Using Wavelet Coefficients. Journal of Neuroscience Methods. https://doi.org/10.1016/j.jneumeth.2005.04.013

14. Doğan, O. (2016). Uyarlamalı Sinirsel Bulanık Çıkarım Sisteminin (ANFIS) Talep Tahmini İçin Kullanımı ve Bir Uygulama. Dokuz Eylül Üniversitesi İktisadi ve İdari Bilimler Dergisi. https://doi.org/10.24988/deuiibf.2016311513

15. Jang, J. S. R. (1993). ANFIS: Adaptive-Network-Based Fuzzy Inference System. IEEE Transactions on Systems, Man and Cybernetics. https://doi.org/10.1109/21.256541

16. Konar, M., \& Bagiş, A. (2009). Uçuş Kontrol Sistemi Hız Parametresinin Adaptif Ağ Yapılı Bulanık Sonuç Çıkarım Sistemi Kullanılarak Belirlenmesi. 2009 IEEE 17th Signal Processing and Communications Applications Conference, SIU 2009. https://doi.org/10.1109/SIU.2009.5136565. 